\title{
Spectroscopic Analysis of Heterogeneous Biocatalysts for Biodiesel Production from Expired Sunflower Cooking Oil
}

\author{
Enoch Wembabazi, ${ }^{1}$ Patrick Joram Mugisha, ${ }^{2}$ Asumani Ratibu, ${ }^{2}$ Deborah Wendiro, ${ }^{2}$ \\ Joseph Kyambadde, ${ }^{1}$ and Peter California Vuzi ${ }^{1}$ \\ ${ }^{1}$ Department of Biochemistry and Sports Science, Makerere University, P.O. Box 7062, Kampala, Uganda \\ ${ }^{2}$ Department of Product Development, Uganda Industrial Research Institute, P.O. Box 7086, Kampala, Uganda
}

Correspondence should be addressed to Peter California Vuzi; pvuzi@cns.mak.ac.ug

Received 29 July 2015; Revised 20 November 2015; Accepted 22 November 2015

Academic Editor: Feride Severcan

Copyright (C) 2015 Enoch Wembabazi et al. This is an open access article distributed under the Creative Commons Attribution License, which permits unrestricted use, distribution, and reproduction in any medium, provided the original work is properly cited.

\begin{abstract}
The study characterized heterogeneous biocatalyst synthesized from sucrose, saw dust, and chicken egg shells using Fourier Transform Infrared (FTIR) spectroscopy coupled with Attenuated Total Reflectance (ATR) technique. Acidic sulphonate (-SO $\left.{ }_{3} \mathrm{H}\right)$ groups were more visible in the spectrum generated for carbonized and sulphonated sucrose than in carbonized and sulphonated saw dust. This was highlighted further by the significantly higher conversion percentage achieved for sulphonated sucrose (62.5\%) than sulphonated saw dust $(46.6 \%)$ during esterification of expired sunflower oil $(p=0.05)$. The spectra for calcinated egg shells also showed that the most active form of calcium oxide was produced at calcination temperature of $1000^{\circ} \mathrm{C}$. This was confirmed in the single-step transesterification reaction in which calcium oxide generated at $1000^{\circ} \mathrm{C}$ yielded the highest biodiesel (87.8\%) from expired sunflower oil. The study further demonstrated the versatility of the FTIR technique in qualitative analysis of biodiesel and regular diesel by confirming the presence of specific characteristic peaks of diagnostic importance. These findings therefore highlight the potential of FTIR-ATR as an inexpensive, fast, and accurate diagnostic means for easy identification and characterization of different materials and products.
\end{abstract}

\section{Introduction}

Several methods are currently employed in the study of materials, including X-ray fluorescence (XRF), X-ray diffraction (XRD), and scanning electron microscopy (SEM). However, these methods have several disadvantages including high cost of analysis per sample, relatively large sample requirement, low reproducibility, and safety concerns with use of Xray equipment $[1,2]$. Further, sample analysis using these techniques is tedious with lengthy sample preparatory steps, which makes working on large samples laborious [2].

These problems could be significantly reduced by using Fourier transform infrared spectroscopy (FTIR), a rapid, simple, and economic tool for studying materials, catalytic activity, and products from chemical reactions [3]. Besides, this technique is precise and nondestructive, requires small samples, is easily reproducible, has less need for messy chemicals, and permits the qualitative and quantitative identification of components in solids and liquids $[4,5]$.

Infrared spectroscopy may be defined as the triggering of vibrations in molecules of a sample through irradiation with infrared light, with the aim of producing a finger print of the sample with absorption peaks which correspond to bonds between the atoms that make up the molecule [6]. The intensity and wavelength of radiation absorbed or transmitted can be measured, thus providing a basis for detection and quantification of functional groups and molecules [7].

The use of FTIR spectroscopy for analyzing catalytic activity is increasingly becoming popular since it can identify chemical bonds in molecules by producing their infrared spectra [8], thus being deemed suitable for verifying presence of desired functional groups in catalysts or for structure elucidation [3]. Coupled with an attenuated total reflectance (ATR) accessory, the technique shortens the time of sample 
preparation and eases spectral reproducibility, thus making sample analysis faster.

Previous investigators have successively used FTIR spectroscopy to characterize both homogeneous and heterogeneous catalysts $[9,10]$. For instance, Engin et al. [11] first demonstrated the effect of different calcination temperatures on heterogeneous biocatalysts from egg shells using FTIR spectroscopy and were able to identify the key functional groups involved. Another study indicated the use of FTIRATR spectroscopy to identify acidic catalytic $-\mathrm{SO}_{3} \mathrm{H}$ groups on sulfonated biochar catalyst, with great ease [12], thus illustrating the wide applicability of this method in studying catalyst activity [9].

However, few studies have demonstrated FTIR-ATR spectroscopy as a stand-alone analytical tool for characterization and selection of catalysts and characterization of reactants and products of transesterification. Moreover, there is a growing need for rapid and simple tools for analysis of fatty acid methyl esters in the production chain of biodiesel industries [5]. The objective of this study was to show the ability of FTIR-ATR spectroscopy as a rapid and reproducible qualitative analytical tool of liquids and solids that could replace the more laborious official methods such as gas chromatography, X-ray fluorescence, and X-ray diffraction spectroscopy in qualitative analysis.

In this study, three heterogeneous biocatalysts synthesized from locally available materials, namely, chicken eggshells, sucrose, and saw dust, were characterized using FTIR-ATR spectroscopy in the midinfrared region to investigate their catalytic potential. Subsequently, the catalysts were employed in single-step transesterification and esterification reactions using expired sunflower oil. The biodiesel produced from the single-step transesterification and regular diesel from a local filling station were similarly analyzed using FTIR-ATR spectroscopy for diagnostic purposes as well as identification of differences between the two products.

\section{Materials and Methods}

2.1. Materials. Egg shells were collected from local egg vendors; sucrose (table sugar) was purchased from a local shop, while saw dust was outsourced from a local carpentry establishment. The saw dust was graded using a fine mesh, dried, and stored under dry conditions. Methanol (98\% analytical grade) and concentrated sulphuric acid (98\%) were purchased from the local chemical supplier. Off-shelf cooking sunflower oil was collected from a disposal point of a selected local supermarket in Kampala city.

\subsection{Methods}

2.2.1. Preparation of Heterogeneous Base Catalyst. The egg shells were washed with warm distilled water to remove dirt, oven-dried at $100^{\circ} \mathrm{C}$ for 24 hours [7], and thereafter crushed in a motorized blender (Electromix). About $200 \mathrm{~g}$ of crushed shells was calcinated in a muffle furnace (Nabertherm model $\mathrm{L} 5 / \mathrm{C6}$ ) at different temperature ranges $500-1000^{\circ} \mathrm{C}$ for 4

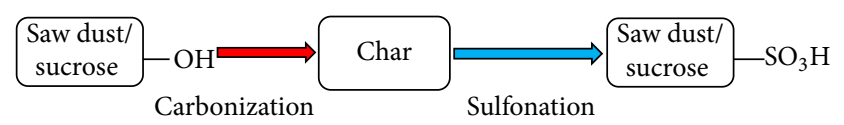

FIGURE 1: Schematic preparation of saw dust and sucrose acid catalysts. Carbonization process removes volatile compounds like phenols from sawdust producing char; sulfonation adds $\left(-\mathrm{SO}_{3} \mathrm{H}\right)$ group to the char forming carbonized + sulfonated saw dust or sucrose catalyst.

hours. The calcinated material (char) was left to cool and then stored in a desiccator.

2.2.2. Preparation of Heterogeneous Acid Catalysts. The acid catalysts were prepared from saw dust and sucrose according to Guo et al. [13] with slight modifications. Briefly, the saw dust and sucrose were partially carbonized in a muffle furnace at $400^{\circ} \mathrm{C}$ under dry nitrogen. The carbonized material (char) was washed with hot distilled water and oven-dried at $105^{\circ} \mathrm{C}$ for 12 hours.

The resulting material was sulfonated by adding $5 \mathrm{~mL}$ of concentrated sulphuric acid (98\%) to $5 \mathrm{~g}$ of the char and the mixture was placed in an oven at $150^{\circ} \mathrm{C}$ for 2 hours (Figure 1). The mixture was left to cool and successively washed with hot distilled water until a neutral $\mathrm{pH}$ of the wash water was achieved. The material was dried in a hot air oven (Memmert UFE 600) at $105^{\circ} \mathrm{C}$ for 48 hours, cooled in a desiccator, and stored in dry containers.

2.2.3. FTIR-ATR Spectroscopic Analysis. FTIR spectra of the calcinated egg shells, solid acid catalysts, biodiesel, and regular diesel were obtained in ATR mode with a Perkin Elmer Spectrum Two spectrophotometer equipped with a Universal Attenuated Total Reflectance (UATR) accessory (Version 10.4, USA). The spectrophotometer was run on software NISO2 and different spectra were obtained in the midinfrared region.

For liquid samples, $0.1 \mathrm{~mL}$ of sample was spread evenly on the diamond crystal of the ATR to obtain the spectra. Each spectrum was a result of four scans done at a resolution of $4 \mathrm{~cm}^{-1}$ over a wavenumber ranging from 4000 to $450 \mathrm{~cm}^{-1}$. For solids, the sample was ground to fine powder using a mortar and pestle and then about $0.01 \mathrm{~g}$ of the sample was spread on the diamond ATR crystal. One spectrum was recorded per sample using air as a reference. The diamond crystal was cleaned using a tissue soaked in pure distilled water, between successive sample runs.

2.2.4. Transesterification and Esterification of Sunflower Oil. Transesterification was done according to Dehkhoda and Ellis [12] with slight modifications, using egg shells calcinated at different temperatures. Briefly, $5 \%(\mathrm{w} / \mathrm{w})$ of the calcinated shell was mixed with $28 \mathrm{~mL}$ of methanol and heated to $40^{\circ} \mathrm{C}$. The mixture was added to $88 \mathrm{~g}(100 \mathrm{~mL})$ of oil and heated to $60^{\circ} \mathrm{C}$ with constant stirring for 120 minutes. The reaction was stopped, residual catalyst sieved off, glycerol decanted off, and biodiesel was washed with hot deionized distilled water. 
Esterification was conducted using $1 \%(\mathrm{w} / \mathrm{w})$ solid acid catalyst, which was mixed with $28 \mathrm{~mL}$ of methanol at room temperature, and added to the warm oil $\left(50^{\circ} \mathrm{C}\right)$ and gently stirred for 180 minutes. The biodiesel yield was determined from the following equations:

Transesterification yield (\%)

$$
=\left(\frac{\text { Weight of refined methyl esters }}{\text { weight of used oil }}\right) \times 100,
$$

Esterification yield (\%)

$$
\begin{aligned}
= & \left(\frac{\text { Initial FFA content }- \text { final FFA content }}{\text { Initial FFA content }}\right) \\
& \times 100,
\end{aligned}
$$

where FFA is free fatty acids.

\section{Results and Discussion}

3.1. Effect of Calcination Temperature on Egg Shells. The FTIR spectra for the eggshells before and after calcinations at 500, $600,700,800,900$, and $1000^{\circ} \mathrm{C}$ are shown in Figure 2. Raw eggshells showed medium bands at $1396 \mathrm{~cm}^{-1}, 872 \mathrm{~cm}^{-1}$, and $711 \mathrm{~cm}^{-1}$ associated with vibrations of carbonate $\left(\mathrm{CO}_{3}{ }^{2-}\right)$ groups [11]. The band at $1396 \mathrm{~cm}^{-1}$ represented the asymmetric $\mathrm{C}-\mathrm{O}$ stretch, $872 \mathrm{~cm}^{-1}$ represented the out-of-plane bend, and $711 \mathrm{~cm}^{-1}$ represented the in-plane bend.

Calcination of egg shells at $500^{\circ} \mathrm{C}$ eliminated organic matter like protein strands and produced sharp bands at $1402 \mathrm{~cm}^{-1}, 891 \mathrm{~cm}^{-1}$, and $712 \mathrm{~cm}^{-1}$ attributed to calcium carbonate [14]. The intensity of the sharp peaks reduced as calcination temperature increased from 500 to $700^{\circ} \mathrm{C}$, possibly signifying the gradual thermal decomposition of carbonate molecules and subsequent emergence of calcium oxide and calcium hydroxide [11].

At temperatures higher than $700^{\circ} \mathrm{C}$, there was significant reduction in the carbonate bands, which corresponded to increased rate of decomposition of carbonates [15]. The presence of diminished carbonate bands in egg shells calcinated at 800 and $900^{\circ} \mathrm{C}$ showed that the transformation into calcium oxide $(\mathrm{CaO})$ was incomplete due to insufficient calcination temperature and time [11].

Conversely, a strong and wide peak corresponding to $\mathrm{Ca}-\mathrm{O}$ bonds appears in the $500 \mathrm{~cm}^{-1}$ region for egg shells calcinated above $700^{\circ} \mathrm{C}$ (Figure 2(b)). At $1000^{\circ} \mathrm{C}$, all the carbonate bands were eliminated due to complete desorption of carbon dioxide from the eggshells, thus producing more basic sites $(\mathrm{CaO})$ that are essential for transesterification to occur $[14,16,17]$.

3.2. Effect of Carbonization and Sulphonation on Sucrose. FTIR spectral wave numbers of sucrose (Table 1) reveal variations in the physical structure following carbonization and sulphonation treatments (Figure 3). The spectrum for untreated sucrose (3A) showed three distinct absorption zones at $3500-3000 \mathrm{~cm}^{-1}, 1500-1280 \mathrm{~cm}^{-1}$ and a finger print region $1200-450 \mathrm{~cm}^{-1}$.

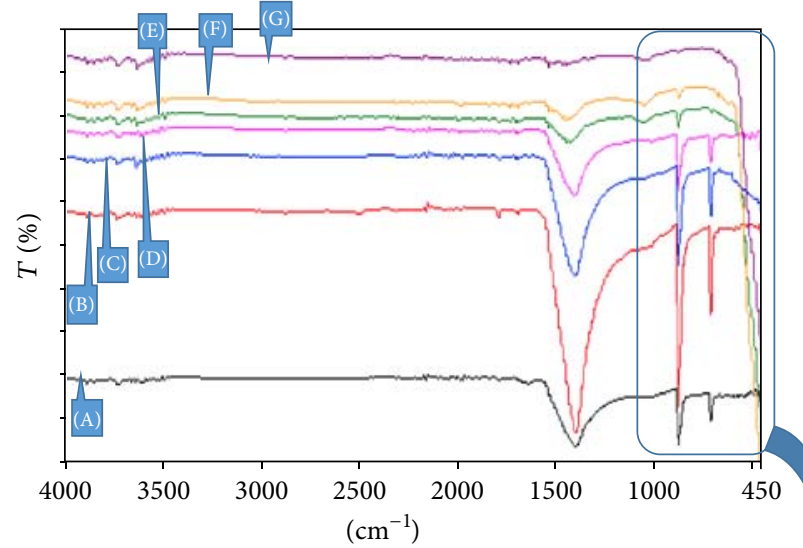

(a)

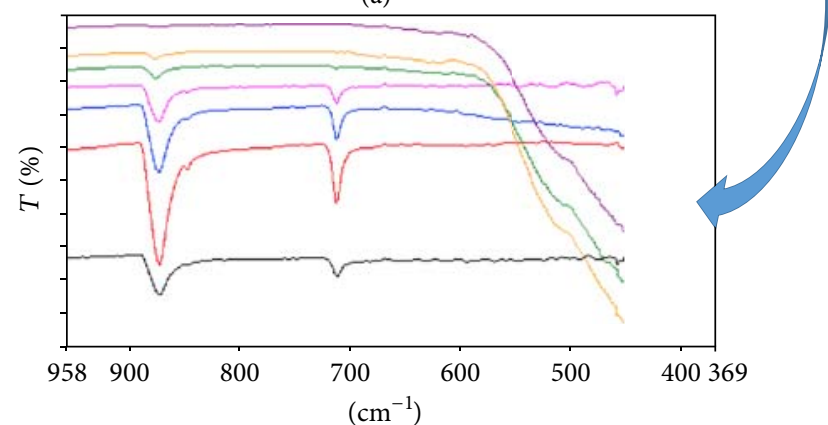

(b)

FIGURE 2: Raw FTIR spectra of eggshells calcinated at different temperatures of 500 (B), 600 (C), 700 (D), 800 (E), 900 (F), and $1000^{\circ} \mathrm{C}(\mathrm{G})$. Uncalcinated egg shell (A) was used as control. Gradual decomposition of carbonates (a) occurred with increasing calcination temperature, leading to inclinations in spectra of $(\mathrm{E}),(\mathrm{F})$, and $(\mathrm{G})$ as seen in (b) due to emergence of calcium oxide bond.

The absorption zone in the $3500-3000 \mathrm{~cm}^{-1}$ region corresponded to an $\mathrm{O}-\mathrm{H}$ vibration and the small peaks next to it represent aliphatic $\mathrm{C}-\mathrm{H}$ vibrations. The absorption zone in the $1500-1280 \mathrm{~cm}^{-1}$ region represented single-bond vibrations of $\mathrm{O}-\mathrm{C}-\mathrm{H}$ and $\mathrm{C}-\mathrm{C}-\mathrm{H}$, while the intense stretches in the finger print region represent $\mathrm{C}-\mathrm{O}-\mathrm{H}$ and $\mathrm{C}-\mathrm{O}-\mathrm{C}$ vibrations. This spectrum $(3 \mathrm{~A})$ is similar to that of sucrose reported in previous studies $[18,19]$.

Subsequent partial carbonization of sucrose (Figure 3(b)) produced a change in spectrum possibly due to loss of bonds in the key regions previously identified in raw sucrose. In particular, reduction in the intensity of the $\mathrm{O}-\mathrm{H}$ band in the $3500-3000 \mathrm{~cm}^{-1}$ region is likely to be a result of the dehydration process leading to loss of $\mathrm{O}-\mathrm{H}$ bonds due to high carbonization temperature [20]. Carbonization also produced a new peak at $1707 \mathrm{~cm}^{-1}$, corresponding to $\mathrm{C}=\mathrm{O}$ vibration [21].

The peaks at wave numbers $1590 \mathrm{~cm}^{-1}$ and $1420 \mathrm{~cm}^{-1}$ most probably correspond to $\mathrm{C}=\mathrm{C}$ stretches, indicative of aromatic groups. In addition, the $\mathrm{C}-\mathrm{O}$ stretches and $\mathrm{O}-\mathrm{H}$ bending vibrations in the $1239-986 \mathrm{~cm}^{-1}$ region are significantly diminished probably due to heat. There is broad band also in the $3700-1800 \mathrm{~cm}^{-1}$ region that could be a result 
TABLE 1: FTIR spectra represented as wave numbers for untreated sucrose (A), carbonized sucrose (B), and carbonized + sulphonated sucrose (C).

\begin{tabular}{|c|c|c|c|c|c|}
\hline $\begin{array}{l}\text { Wave numbers } \\
\text { A }\end{array}$ & Group attributed & $\begin{array}{c}\text { Wave numbers } \\
\text { B }\end{array}$ & Group attributed & $\begin{array}{c}\text { Wave numbers } \\
\text { C }\end{array}$ & Group attributed \\
\hline 3325 & $\mathrm{O}-\mathrm{H}$ & 3333 & $\mathrm{O}-\mathrm{H}$ & 2965 & $\mathrm{C}-\mathrm{H}$ \\
\hline 2900 & $\mathrm{C}-\mathrm{H}$ & 1707 & $\mathrm{C}=\mathrm{O}$ & 1769 & $\mathrm{C}=\mathrm{O}$ \\
\hline 1490 & $\mathrm{C}-\mathrm{C}$ & 1590 & $\mathrm{C}=\mathrm{C}$ & 1758 & $\mathrm{C}=\mathrm{O}$ \\
\hline 1430 & $\mathrm{C}-\mathrm{O}$ & 1420 & $\mathrm{C}=\mathrm{C}$ & 1456 & $\mathrm{C}=\mathrm{C}$ \\
\hline 1320 & $\mathrm{C}-\mathrm{O}$ & 1239 & $\mathrm{C}-\mathrm{O}$ & 1376 & $\mathrm{O}=\mathrm{S}$ \\
\hline 1066 & $\mathrm{C}-\mathrm{OH}$ & 986 & $\mathrm{C}-\mathrm{O}$ & 1245 & $-\mathrm{SO}_{3} \mathrm{H}$ \\
\hline 1055 & $\mathrm{C}-\mathrm{OH}$ & & & 1057 & $\mathrm{~S}=\mathrm{O}$ \\
\hline
\end{tabular}

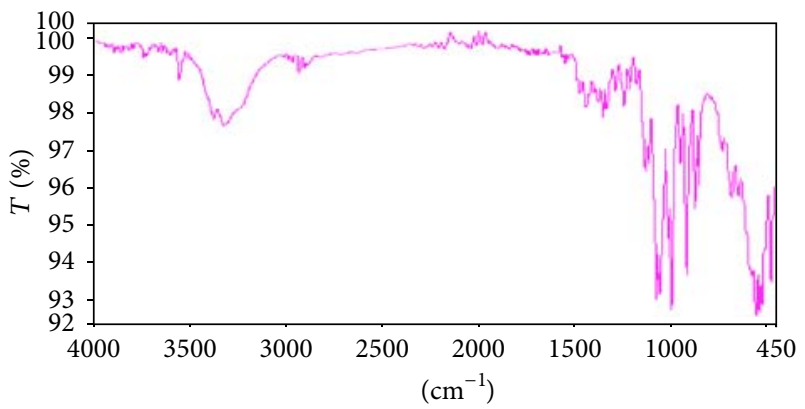

(a)

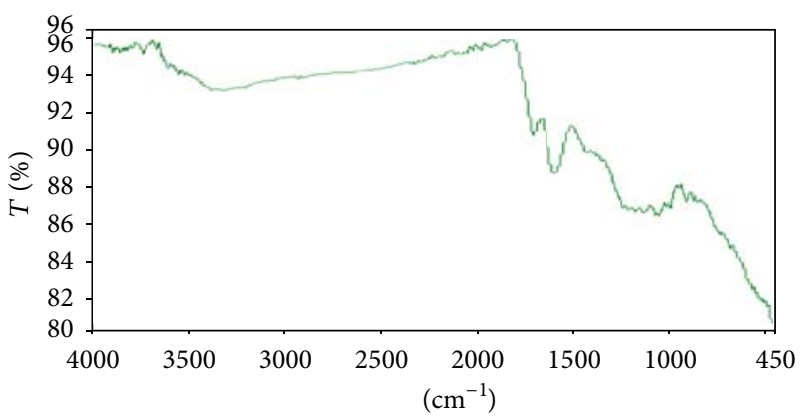

(b)

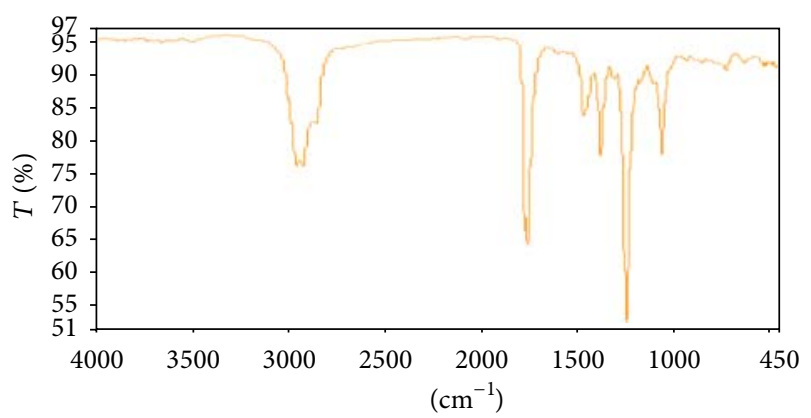

(c)

FIGURE 3: Raw FTIR spectra of sucrose (a), carbonized sucrose (b), and carbonized + sulphonated sucrose (c).

of new hydrogen bonding interactions caused by carbonization, resulting in several oscillation modes in that region [22]. Overall, partial carbonization of sucrose resulted in dehydration and aromatization reactions with subsequent diminution of all major bond peaks previously observed in uncarbonized sucrose [23].

A significant change in the spectrum of carbonized sucrose was observed upon sulphonation with concentrated sulphuric acid (Figure 3(c)). The absence of an $\mathrm{O}-\mathrm{H}$ peak in the 3000-3500 region indicates total dehydration of the sucrose by the concentrated sulphuric acid [21]. On the other hand, the development of an intense aliphatic peak corresponding to $\mathrm{C}-\mathrm{H}$ group around the $2900 \mathrm{~cm}^{-1}$ wave region was observed.

The vibration of $\mathrm{C}=\mathrm{O}$ group at wave numbers 1769 and $1758 \mathrm{~cm}^{-1}$ intensified possibly due to oxidation and esterification of the abundant $\mathrm{O}-\mathrm{H}$ groups in sucrose by $\mathrm{H}_{2} \mathrm{SO}_{4}$. Sharp peaks corresponding to $\mathrm{O}=\mathrm{S}=\mathrm{O}$ group were also observed at 1376 and $1057 \mathrm{~cm}^{-1}$, whereas the intense peak at $1245 \mathrm{~cm}^{-1}$ was attributed to the $-\mathrm{SO}_{3} \mathrm{H}$ group. The formation of such strong sharp bands indicates that sucrose can easily be carbonized, dehydrated, and sulfonated to facilitate the attachment of catalytic $\mathrm{SO}_{3} \mathrm{H}$ acidic groups [24].

3.3. Effect of Carbonization and Sulphonation on Saw Dust. Saw dust on the other hand presented a similar spectrum to that observed in untreated sucrose (Figure 4). There was a broad $\mathrm{O}-\mathrm{H}$ bond also in untreated saw dust (Figure 4(a)) in the $3000-3500 \mathrm{~cm}^{-1}$ region, which could be attributed to cellulose and hemicellulose [25] that are the major carbohydrates in saw dust. A weak $\mathrm{C}-\mathrm{H}$ vibration was observed at the $2883 \mathrm{~cm}^{-1}$ position, confirming the presence of aliphatic groups. Unlike sucrose, a weak $\mathrm{C}=\mathrm{O}$ peak was observed at the $1727 \mathrm{~cm}^{-1}$ region. The region around $1630-1233 \mathrm{~cm}^{-1}$ was characterized by weak alkene $(C=C)$, aromatic $(C=C)$, $\mathrm{CH}_{2}$, and $\mathrm{CH}$ groups including phenolic $\mathrm{OH}$ groups. The most intense peak at $1032 \mathrm{~cm}^{-1}$ could be attributed to $\mathrm{C}-\mathrm{O}$ vibration. The untreated saw dust spectrum observed here was similar to those seen in previous studies $[8,26]$.

Carbonization led to the diminution of certain bonds and intensification of others (Figure 4(b)). The most notable was the reduced intensity of the $\mathrm{O}-\mathrm{H}$ vibration in the $3000-$ $3500 \mathrm{~cm}^{-1}$ as well as diminished $\mathrm{O}-\mathrm{H}$ peak at $1032 \mathrm{~cm}^{-1}$. This reduction in intensity could be attributed to the decomposition of hemicellulose at high carbonization temperatures used in this study. The $\mathrm{C}=\mathrm{O}$ peaks between $1727 \mathrm{~cm}^{-1}$ and 


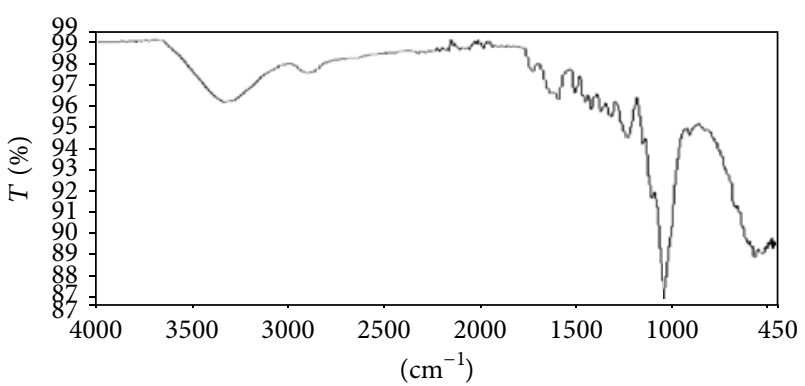

(a)

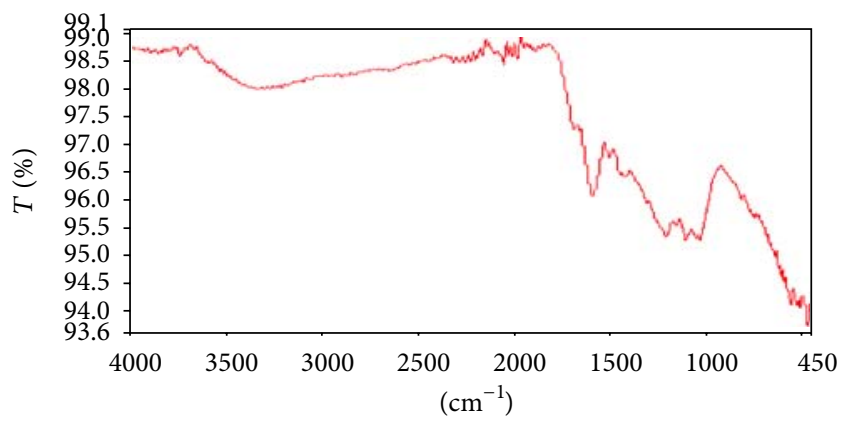

(b)

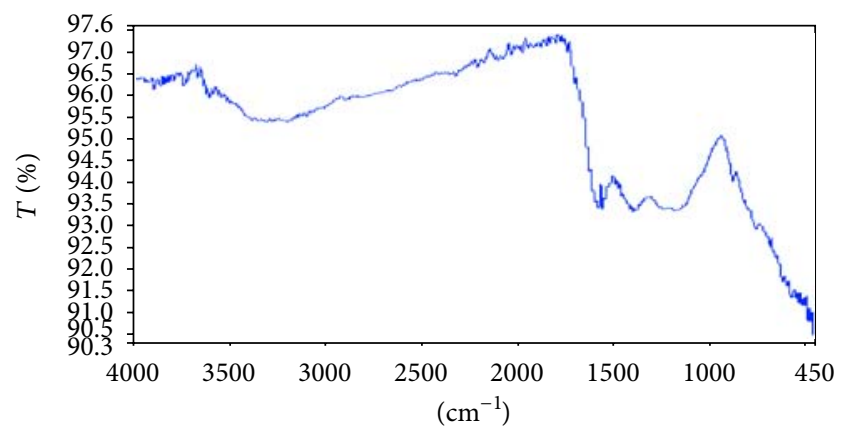

(c)

FIgURE 4: Raw FTIR spectra for dry saw dust (a), carbonized saw dust (b), and carbonized + sulphonated sawdust (c).

$1590 \mathrm{~cm}^{-1}$ were intensified, indicating increased aromatization due to carbonization [27]. As observed in carbonized sucrose (Figure 2(b)), a broad band in the $3700-1800 \mathrm{~cm}^{-1}$ region of carbonized saw dust is likely a result of new hydrogen bonding interactions [22].

Sulphonation of the biochar did not produce significant spectral changes as expected (Figure 4(c)), and, therefore, the spectrum of sulphonated char was similar to that of carbonized saw dust, with minor differences in the 1570$1000 \mathrm{~cm}^{-1}$ region. Other than the newly emerged weak band at $1555 \mathrm{~cm}^{-1}$, no bands could be attributed directly to acidic groups as in the case of sucrose spectrum. Other bonds identified in the spectra of raw sawdust, carbonized sawdust, and carbonized sulphonated saw dust are presented in Table 2.

3.4. Transesterification and Esterification of Expired Sunflower Cooking Oil. Single-step transesterification using eggshell

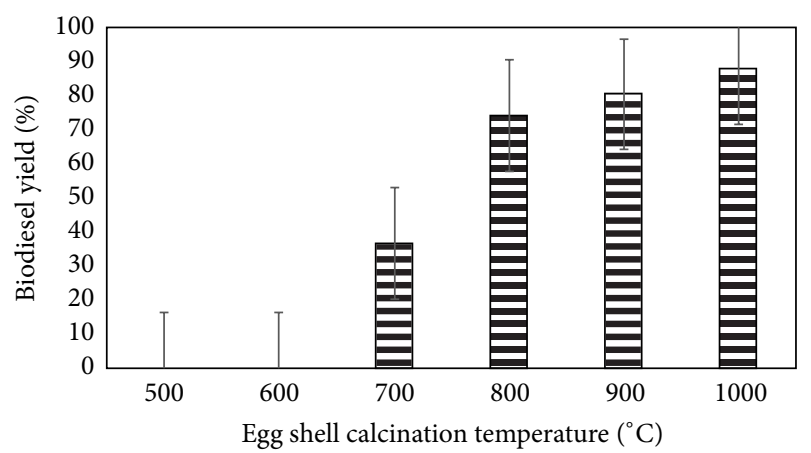

FIGURE 5: Single-step transesterification of sunflower oil using egg shells calcinated at different temperatures. Experimental conditions: temperature $60^{\circ} \mathrm{C}$, methanol/oil ratio $6: 1$, catalyst load $5 \%$ (wt/wt), and time 120 minutes.

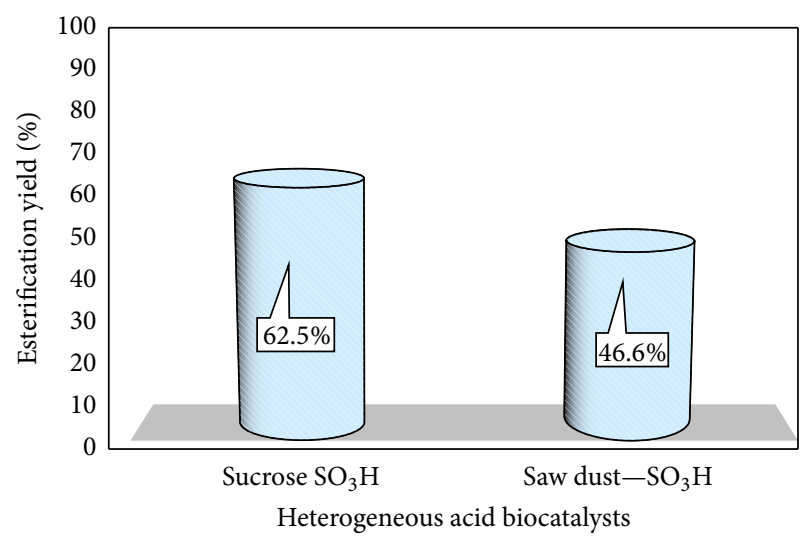

FIGURE 6: Esterification using heterogeneous acid biocatalysts. Experiment conditions: methanol/oil ratio $6: 1$, temperature $70^{\circ} \mathrm{C}$, time 180 minutes, and catalyst load $1 \%(\mathrm{wt} / \mathrm{wt})$.

calcinated at $1000^{\circ} \mathrm{C}$ produced the highest yield of biodiesel $(87.8 \%)$. The lowest biodiesel yield $(36.6 \%)$ is attained with eggshell calcinated at $700^{\circ} \mathrm{C}$ (Figure 5). This confirms that calcination temperature of shells has an effect on the final yield of biodiesel attained [28]. The low yield of biodiesel attained with catalyst generated at $700^{\circ} \mathrm{C}$ is possibly a result of incomplete conversion of $\mathrm{CaCO}_{3}$ to $\mathrm{CaO}[16,17]$, as evidenced by the FTIR spectra (Figure 2).

On the other hand, sulphonated sucrose produced significantly $(p=0.05)$ higher esterification yield $(62.5 \%)$ than sulphonated saw dust $(46.7 \%)$ under similar reaction conditions (Figure 6). The high catalytic activity of sulfonated sucrose is likely a result of efficient sulfonation, which could have resulted in a catalyst with higher acid density than that of sulfonated sawdust, which showed no clear evidence of sulfonation (Figures 3(c) and 4(c)). A similar study found that sulphonated sucrose had a higher acid density than all other similarly treated carbons such as starch and lignin [13]. The low activity of saw dust catalyst could be due to incomplete carbonization of lignin in sawdust, leaving excess oxygen in the material which limits the number of $-\mathrm{SO}_{3} \mathrm{H}$ groups that could attach onto the carbonized char [13]. 
TABLE 2: Wave numbers of FTIR spectra and associated bonds for untreated saw dust (A), carbonized saw dust (B), and carbonized + sulphonated saw dust (C).

\begin{tabular}{|c|c|c|c|c|c|}
\hline $\begin{array}{l}\text { Wave number } \\
\text { A }\end{array}$ & Group attributed & $\begin{array}{c}\text { Wave number } \\
\text { B } \\
\end{array}$ & Group attributed & $\begin{array}{c}\text { Wave number } \\
\text { C }\end{array}$ & Group attributed \\
\hline 3338 & $\mathrm{O}-\mathrm{H}$ & 3366 & $\mathrm{O}-\mathrm{H}$ & 1555 & $\mathrm{C}=\mathrm{C}$ \\
\hline 2883 & $\mathrm{C}-\mathrm{H}$ & 1594 & $\mathrm{C}=\mathrm{C}$ & 1397 & $\mathrm{~S}=\mathrm{O}$ \\
\hline 1727 & $\mathrm{C}=\mathrm{O}$ & 1208 & $\mathrm{C}-\mathrm{O}$ & 1155 & $\mathrm{~S}-\mathrm{O}^{-}$ \\
\hline 1596 & $\mathrm{C}=\mathrm{C}$ & 1106 & $\mathrm{C}-\mathrm{O}$ & & \\
\hline 1233 & $\mathrm{C}=\mathrm{C}$ & 1028 & $\mathrm{C}-\mathrm{O}$ & & \\
\hline 1032 & $\mathrm{C}-\mathrm{O}$ & & & & \\
\hline 559 & $\mathrm{C}-\mathrm{C}$ & & & & \\
\hline
\end{tabular}

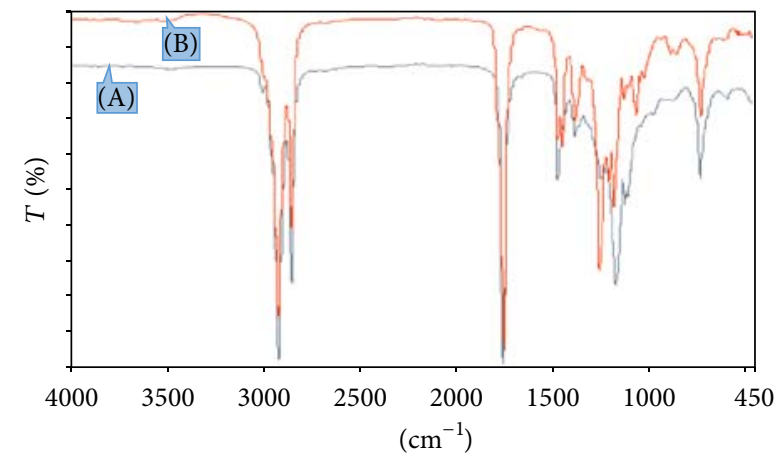

Figure 7: Raw FTIR spectra for expired sunflower oil (A) and biodiesel (B).

\section{Characterization of Biodiesel and Regular Diesel Using FTIR-ATR Spectroscopy}

FTIR spectra of biodiesel and expired sunflower cooking oil are presented in Figure 7 and the various absorption peaks of biodiesel are presented in Table 3 . There were no significant peaks in the regions $1700-2800 \mathrm{~cm}^{-1}$ and $3000-4000 \mathrm{~cm}^{-1}$ for both expired sunflower cooking oil and biodiesel spectra [29], but both showed strong peaks between 2800 and $3000 \mathrm{~cm}^{-1}$ corresponding to $\mathrm{C}-\mathrm{H}$ vibrations. Major differences between the two spectra lie in the $1500-500 \mathrm{~cm}^{-1}$ and are mainly exhibited by esters (biodiesel), as a result of $\mathrm{C}-\mathrm{O}$ vibrations. The main characteristic peak for biodiesel occurs at $1245 \mathrm{~cm}^{-1}(\mathrm{C}-\mathrm{O})$ and corresponds to the proportion of fatty acid methyl esters [30]. Other peaks diagnostic for biodiesel were identified at positions $1742 \mathrm{~cm}^{-1}(\mathrm{C}=\mathrm{O})$ and $1057 \mathrm{~cm}^{-1}$ (C-O) similar to those identified in other studies $[5,31]$.

The spectrum for regular diesel showed some similarities to that of biodiesel, particularly in the $3000-2700 \mathrm{~cm}^{-1}$ region (Figure 8 ). There was also a mild $\mathrm{C}=\mathrm{O}$ vibration detected in the $1750-1780 \mathrm{~cm}^{-1}$ region, unlike the sharp vibration for biodiesel around a similar position as well as a $\mathrm{C}-\mathrm{O}$ ester diagnostic bond at $1246 \mathrm{~cm}^{-1}$. In contrast, other studies showed no peak in the $1750-1780 \mathrm{~cm}^{-1}$ region for diesel [5, 32]. Other peaks for regular diesel are presented in Table 4.
TABLE 3: Wave numbers responsible for different peaks of biodiesel (BD).

\begin{tabular}{|c|c|c|c|}
\hline $\begin{array}{l}\text { Wave number } \\
\text { of BD }\left(\mathrm{cm}^{-1}\right)\end{array}$ & $\begin{array}{c}\text { Group } \\
\text { attributed }\end{array}$ & $\begin{array}{c}\text { Vibration } \\
\text { type }\end{array}$ & $\begin{array}{c}\text { Absorption } \\
\text { intensity }\end{array}$ \\
\hline 2923 & $\mathrm{C}-\mathrm{H}$ & Stretch & Strong \\
\hline 2880 & $\mathrm{C}-\mathrm{H}$ & Stretch & Strong \\
\hline 2853 & $\mathrm{C}-\mathrm{H}$ & Stretch & Strong \\
\hline 1742 & $\mathrm{C}=\mathrm{O}$ & Stretch & Very strong \\
\hline 1463 & $-\mathrm{CH}_{2}$ & $\begin{array}{l}\text { In-plane } \\
\text { bend }\end{array}$ & Medium \\
\hline 1435 & $-\mathrm{CH}_{3}$ & $\begin{array}{c}\text { Asymmetric } \\
\text { bend }\end{array}$ & Medium \\
\hline 1371 & $\mathrm{O}-\mathrm{CH}_{2}$ & Bend & Medium \\
\hline 1245 & $\mathrm{O}-\mathrm{CH}_{3}$ & Stretch & Strong \\
\hline 1184 & $\mathrm{C}-\mathrm{C}$ & Bend & Weak \\
\hline 1169 & $\mathrm{C}-\mathrm{C}$ & Bend & Strong \\
\hline 1057 & $\mathrm{C}-\mathrm{O}$ & Bend & Medium \\
\hline 722 & $\mathrm{C}-\mathrm{H}$ & Bend & Medium \\
\hline
\end{tabular}

\section{Conclusion}

This study established that FTIR-ATR spectroscopy is a quick analytical technique that can be used to confirm the presence of key functional groups on heterogeneous biocatalysts, thus helping to predict activity of catalysts. The FTIR spectra of calcinated egg shells showed gradual decomposition of calcium carbonate with subsequent emergence of calcium oxide as temperature increased. Single-step transesterification of the expired sunflower oil showed that $\mathrm{CaO}$ generated from egg shell at $1000^{\circ} \mathrm{C}$ produced the highest biodiesel yield $(87.8 \%)$. The spectra for carbonized sulphonated sucrose confirmed the presence of sulphonate $\left(-\mathrm{SO}_{3} \mathrm{H}\right)$ groups, which make the biochar catalytically active, as confirmed by the high esterification yield of $62.5 \%$. Conversely, the sulphonated sawdust showed no clear evidence of the presence of acidic $\left(-\mathrm{SO}_{3} \mathrm{H}\right)$ groups, thus explaining the low esterification conversion achieved with this catalyst. The infrared spectra for biodiesel and regular diesel further help confirm that FTIR-ATR spectroscopy can be rapidly used for final product verification as compared to more costly chromatographic techniques such as HPLC and gas chromatography. 


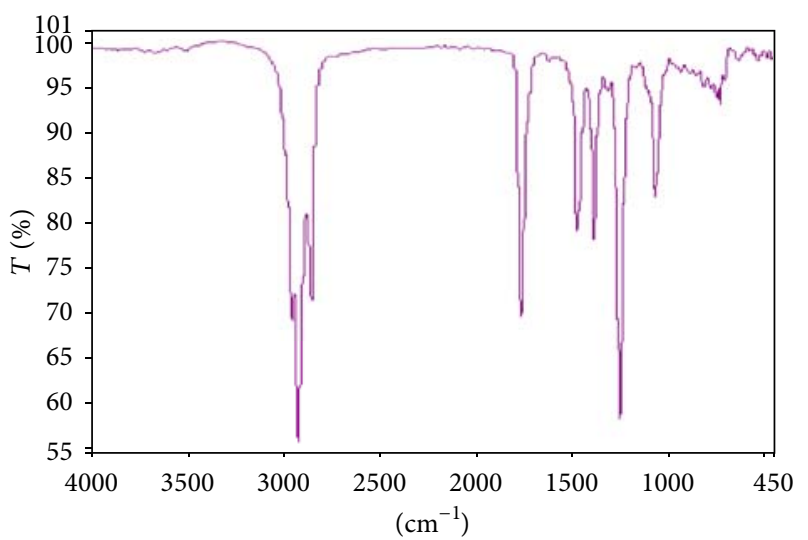

FIGURE 8: Raw FTIR spectrum of regular diesel.

TABLE 4: FTIR wave numbers for different peaks of regular diesel.

\begin{tabular}{lccc}
\hline $\begin{array}{l}\text { Wave number } \\
\text { diesel }\left(\mathrm{cm}^{-1}\right)\end{array}$ & $\begin{array}{c}\text { Group } \\
\text { attributed }\end{array}$ & $\begin{array}{c}\text { Vibration } \\
\text { type }\end{array}$ & $\begin{array}{c}\text { Absorption } \\
\text { intensity }\end{array}$ \\
\hline 2954 & $\mathrm{C}-\mathrm{H}$ & Stretch & Strong \\
2922 & $\mathrm{C}-\mathrm{H}$ & Stretch & Strong \\
2853 & $\mathrm{C}-\mathrm{H}$ & Stretch & Medium \\
1770 & $\mathrm{C}=\mathrm{O}$ & Stretch & Medium \\
1758 & $\mathrm{C}=\mathrm{O}$ & Stretch & Strong \\
1456 & $\mathrm{C}=\mathrm{C}$ & Stretch & Medium \\
1376 & $\mathrm{C}=\mathrm{C}$ & Stretch & Medium \\
1246 & $\mathrm{C}-\mathrm{O}$ & Stretch & Strong \\
1057 & $\mathrm{C}-\mathrm{O}$ & Stretch & Medium \\
722 & & Out-of- & \\
& $\mathrm{C}-\mathrm{H}$ & plane & Medium \\
& & bend & \\
\hline
\end{tabular}

These findings therefore imply that FTIR-ATR spectroscopy may be adopted as an inexpensive alternative for quick analysis of materials and products of chemical reactions.

\section{Conflict of Interests}

The authors declare that there is no conflict of interests regarding the publication of this paper.

\section{Acknowledgments}

The authors acknowledge financial support from Honorable Justice Simon Byabakama and Mrs Byabakama Dorothy towards this study. This work also received support from the Department of Biochemistry and Sports Science, Makerere University, and the Departments of Chemistry, Microbiology and Biotechnology of Uganda Industrial Research Institute (UIRI), which provided technical as well as infrastructural support to the study.

\section{References}

[1] G. E. A. Swann and S. V. Patwardhan, "Application of Fourier Transform Infrared Spectroscopy (FTIR) for assessing biogenic silica sample purity in geochemical analyses and palaeoenvironmental research," Climate of the Past, vol. 7, no. 1, pp. 65-74, 2011.

[2] T. Springfield, Application of FTIR for Quantification of Alkali in Cement, University of North Texas, Denton, Tex, USA, 2011.

[3] V. A. E. Barrios, J. R. R. Méndez, N. V. P. Aguilar, G. A. Espinosa, and J. L. Dávila, "FTIR—an essential characterization technique for polymeric," in Infrared Spectroscopy-Materials Science, Engineering and Technology, T. Theophanides, Ed., chapter 9, InTech, Rijeka, Croatia, 2012.

[4] M. P. Tucker, Q. A. Nguyen, F. P. Eddy, K. L. Kadam, L. M. Gedvilas, and J. D. Webb, "Fourier transform infrared quantitative analysis of sugars and lignin in pretreated softwood solid residues," Applied Biochemistry and Biotechnology-Part A: Enzyme Engineering and Biotechnology, vol. 91, no. 1, pp. 5161, 2001.

[5] M. Bradley, Biodiesel (FAME) Analysis by FT-IR, Thermo Scientific, 2007.

[6] B. Stuart, Infrared Spectroscopy, Wiley, 2005.

[7] D. J. Holme and H. Peck, Spectroscopy, Analytical Biochemistry, Pearson Education, 3rd edition, 1998.

[8] M. Z. Norashikin and M. Z. Ibrahim, "Fabrication and characterization of sawdust composite biodegradable film," World Academy of Science, Engineering and Technology, vol. 65, pp. 864-868, 2010.

[9] S. A. Tromp, ATR-FTIR in catalysis: study of homogeneous, heterogeneous and biocatalysts: TU Delft [Ph.D. thesis], Delft University of Technology, Delft, The Netherlands, 2011.

[10] D. Lee, "Preparation of a sulfonated carbonaceous material from lignosulfonate and its usefulness as an esterification catalyst," Molecules, vol. 18, no. 7, pp. 8168-8180, 2013.

[11] B. Engin, H. Demirtaş, and M. Eken, "Temperature effects on egg shells investigated by XRD, IR and ESR techniques," Radiation Physics and Chemistry, vol. 75, no. 2, pp. 268-277, 2006.

[12] A. M. Dehkhoda and N. Ellis, "Biochar-based catalyst for simultaneous reactions of esterification and transesterification," Catalysis Today, vol. 207, pp. 86-92, 2013.

[13] F. Guo, Z.-L. Xiu, and Z.-X. Liang, "Synthesis of biodiesel from acidified soybean soapstock using a lignin-derived carbonaceous catalyst," Applied Energy, vol. 98, pp. 47-52, 2012.

[14] N. Tangboriboon, R. Kunanuruksapong, and A. Srivat, "Mesoporosity and phase transformation of bird eggshells via pyrolysis," Journal of Ceramic Processing Research, vol. 13, no. 4, pp. 413-419, 2012.

[15] N. Viriya-Empikul, P. Krasae, B. Puttasawat, B. Yoosuk, N. Chollacoop, and K. Faungnawakij, "Waste shells of mollusk and egg as biodiesel production catalysts," Bioresource Technology, vol. 101, no. 10, pp. 3765-3767, 2010.

[16] J. Boro, D. Deka, and A. J. Thakur, "A review on solid oxide derived from waste shells as catalyst for biodiesel production," Renewable and Sustainable Energy Reviews, vol. 16, no. 1, pp. 904-910, 2012.

[17] A. Jazie, H. Pramanik, A. Sinha, and A. Jazie, "Egg shell as eco-friendly catalyst for transesterification of rapeseed oil: optimization for biodiesel production," International Journal of Sustainable Development and Green Economics, vol. 2, no. 1, pp. 27-32, 2013. 
[18] L. F. Leopold, N. Leopold, H.-A. Diehl, and C. Socaciu, "Quantification of carbohydrates in fruit juices using FTIR spectroscopy and multivariate analysis," Spectroscopy, vol. 26, no. 2, pp. 93-104, 2011.

[19] I. F. Duarte, A. Barros, I. Delgadillo, C. Almeida, and A. M. Gil, "Application of FTIR spectroscopy for the quantification of sugars in mango juice as a function of ripening," Journal of Agricultural and Food Chemistry, vol. 50, no. 11, pp. 3104-3111, 2002.

[20] M. Sevilla and A. B. Fuertes, "The production of carbon materials by hydrothermal carbonization of cellulose," Carbon, vol. 47, no. 9, pp. 2281-2289, 2009.

[21] M. Liu, S. Jia, Y. Gong, C. Song, and X. Guo, "Effective hydrolysis of cellulose into glucose over sulfonated sugarderived carbon in an ionic liquid," Industrial and Engineering Chemistry Research, vol. 52, no. 24, pp. 8167-8173, 2013.

[22] S. Mopoung, A. Sirikulkajorn, D. Dummun, and P. Luethanom, "Nanocarbonfibril in rice flour charcoal," International Journal of Physical Sciences, vol. 7, no. 2, pp. 214-221, 2012.

[23] M. Sevilla and A. B. Fuertes, "Chemical and structural properties of carbonaceous products obtained by hydrothermal carbonization of saccharides," Chemistry-A European Journal, vol. 15, no. 16, pp. 4195-4203, 2009.

[24] V. Mirkhani, M. Moghadam, S. Tangestaninejad, I. Mohammadpoor-Baltork, and M. Mahdavi, "Synthesis, characterization and investigation of catalytic activity of a highly sulfonated carbon solid acid in the synthesis of dihydropyrimidinones under solvent-free conditions," Journal of the Iranian Chemical Society, vol. 8, no. 3, pp. 608-615, 2011.

[25] R. C. Pettersen, "The chemical composition of wood," in The Chemistry of Solid Wood, vol. 207 of Advances in Chemistry, pp. 57-126, American Chemical Society, 1984.

[26] G. Müller, C. Schöpper, H. Vos, A. Kharazipour, and A. Polle, "FTIR-ATR spectroscopic analyses of changes in wood properties during particleand fibreboard production of hardand softwood trees," BioResources, vol. 4, no. 1, pp. 49-71, 2009.

[27] M. Sevilla, J. A. Maciá-Agulló, and A. B. Fuertes, "Hydrothermal carbonization of biomass as a route for the sequestration of $\mathrm{CO}_{2}$ : chemical and structural properties of the carbonized products," Biomass and Bioenergy, vol. 35, no. 7, pp. 3152-3159, 2011.

[28] Z. Wei, C. Xu, and B. Li, "Application of waste eggshell as low-cost solid catalyst for biodiesel production," Bioresource Technology, vol. 100, no. 11, pp. 2883-2885, 2009.

[29] S. Choi and Y. Oh, "Evaluation of biodiesel from animal fats by gas chromatography, FTIR spectroscopy and spray behavior," Advanced Science and Technology Letters, vol. 58, pp. 133-136, 2014.

[30] N. G. Siatis, A. C. Kimbaris, C. S. Pappas, P. A. Tarantilis, and M. G. Polissiou, "Improvement of biodiesel production based on the application of ultrasound: monitoring of the procedure by FTIR spectroscopy," Journal of the American Oil Chemists' Society, vol. 83, no. 1, pp. 53-57, 2006.

[31] T. Yuan, E. Akochi-Koble, D. Pinchuk, and F. R. van de Voort, "FTIR on-line monitoring of biodiesel transesterification," International Journal of Renewable Energy \& Biofuels, vol. 2014, Article ID 178474, 13 pages, 2014.

[32] A. G. Peña, F. A. Franseschi, M. C. Estrada et al., "Fourier transform infrared-attenuated total reflectance (FTIR-ATR) spectroscopy and chemometric techniques for the determination of adulteration in petrodiesel/biodiesel blends," Quimica Nova, vol. 37, no. 3, pp. 392-397, 2014. 

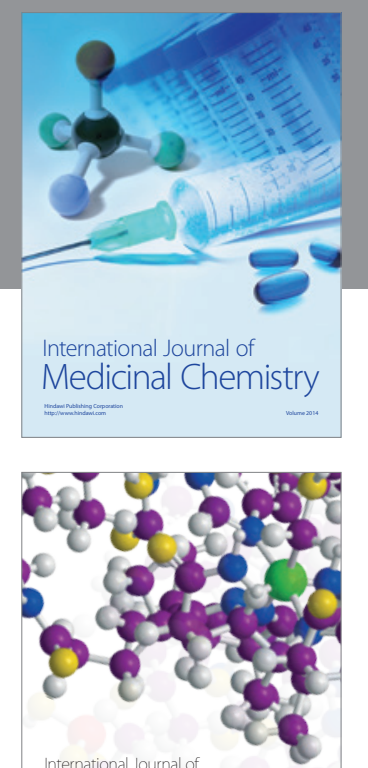

\section{Carbohydrate} Chemistry

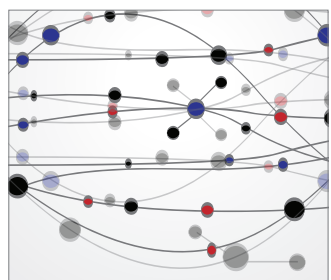

The Scientific World Journal
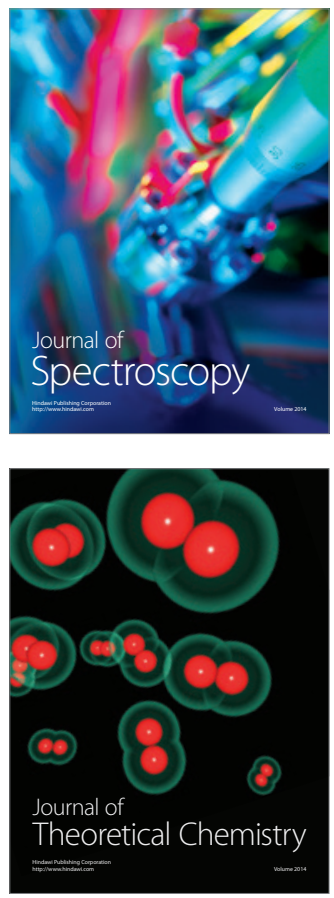
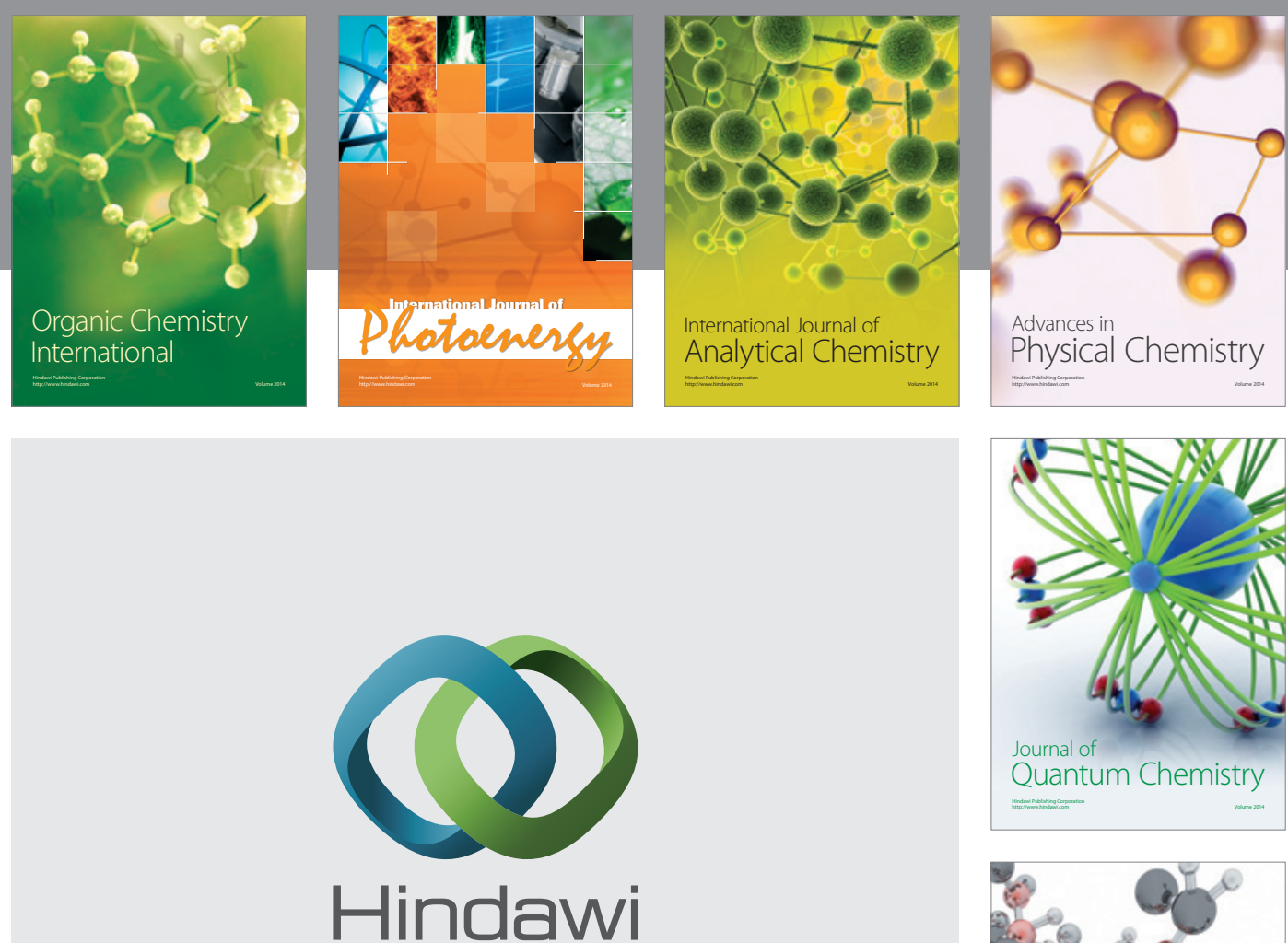

Submit your manuscripts at

http://www.hindawi.com

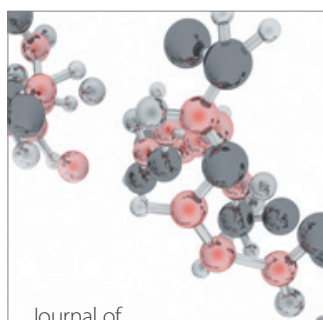

Analytical Methods

in Chemistry

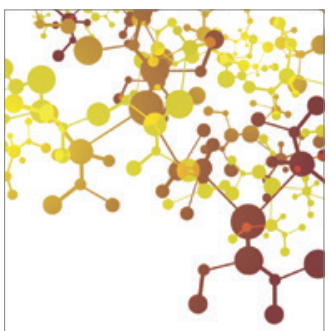

Journal of

Applied Chemistry

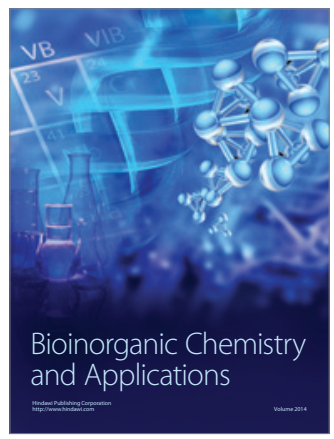

Inorganic Chemistry
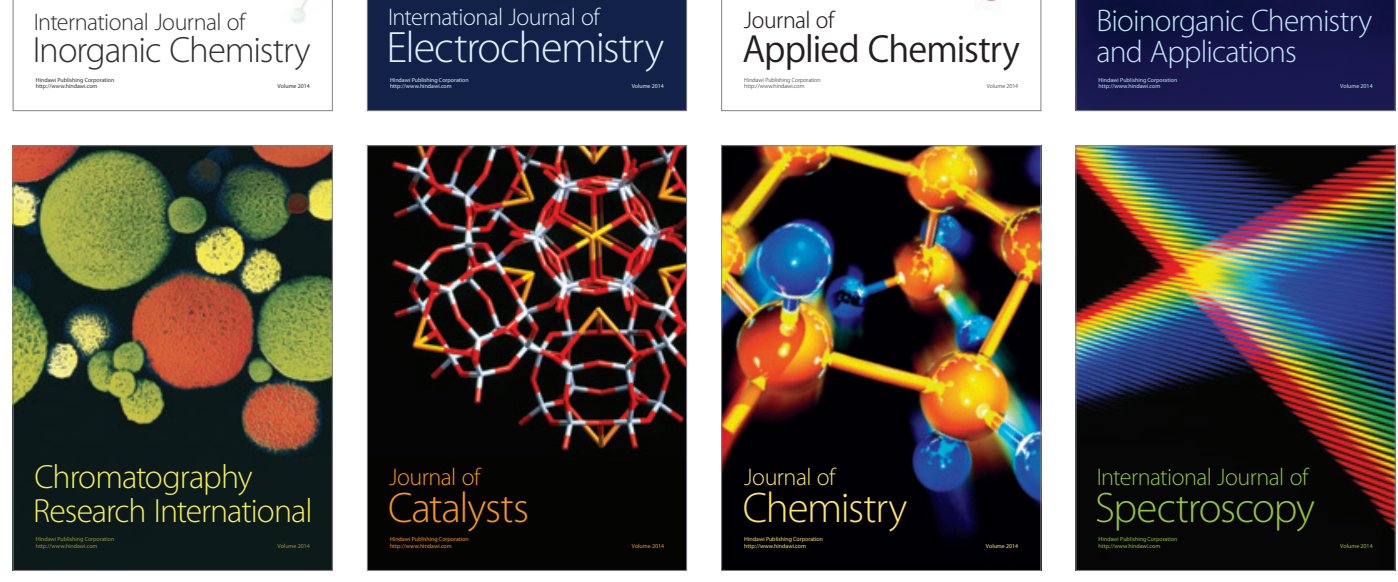